\title{
Asbestos bodies in lungs at necropsy
}

\author{
G. HEFIN ROBERTS
}

From the Southern General Hospital, Glasgow

SYNOPSIS This study was made in Glasgow, Scotland, near an industrial area where ship building is an important industry. Asbestos bodies were found in $23 \%$ of 100 consecutive hospital necropsies, bodies were present in $37 \%$ of the 62 males, none were found in 38 females. These findings are compared with results of other similar surveys. In $85.4 \%$ of cases showing asbestos bodies, hyaline pleural plaques were found. There was one case of asbestosis and three of bronchial carcinoma in the cases showing asbestos bodies.

Asbestos-containing products are today used widely in industry and homes. The relatively few necropsy studies of the prevalence of asbestos bodies in the lungs of urban dwellers have shown that they are found with surprising frequency, and the present investigation was designed to find the incidence of asbestos bodies in lungs from a consecutive series of hospital necropsies in Glasgow.

\section{MATERIALS AND METHODS}

The material was obtained from a series of 100 consecutive adult necropsies performed in a hospital which serves a large urban population of south-west Glasgow, close to the Clyde with its concentration of heavy industry.

At necropsy, thick smears were made on $3 \times 1$ in. $(75 \times 25 \mathrm{~mm}$. $)$ microscope slides from the cut surfaces of the basal segments of both lower lobes. The smears, consisting mainly of red blood cells, were air dried, dehydrated in spirit and alcohol, cleared in xylol and mounted in D.P.X. Three hundred consecutive lowpower fields $(16 \mathrm{~mm}$. objective) were examined from each slide, and the presence of asbestos bodies was confirmed by the $4 \mathrm{~mm}$. objective. Only typical asbestos bodies were accepted for counting (Fig. 1); 'pseudoasbestos' bodies having a black carbonaceous centre, surrounded by a variable amount of yellow coating, were disregarded (Fig. 2). Fragmented asbestos bodies were not accepted for counting; complete bodies could also be found in these cases.

In 81 cases the pleural cavities and diaphragm were examined for hyaline and calcified pleural plaques.

In none of these cases was a detailed occupational history available but a note was made of the patient's present occupation, when available, in the clinical notes. Most of the women were described as 'housewives'; some of the elderly men simply as 'retired' or 'pensioner'; in the remainder there was a wide variety of occupations, most were skilled tradesmen.

Received for publication 28 February 1967.

\section{RESULTS}

AGE AND SEX DISTRIBUTION In the 100 cases there were 62 males and 38 females; the mean age at death was 65 years (range 24 to 85 years). As in any consecutive necropsy series, the middle-aged and elderly

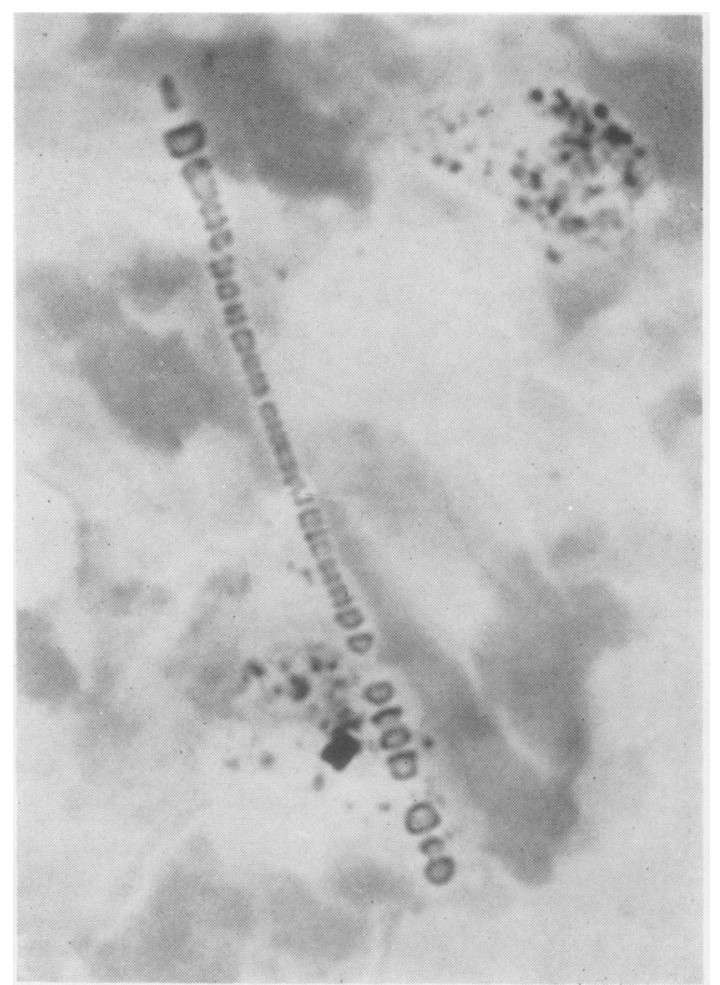

FIG. 1. Segmented asbestos body. Basal lung smear (unstained $\times 11,000$ ). 


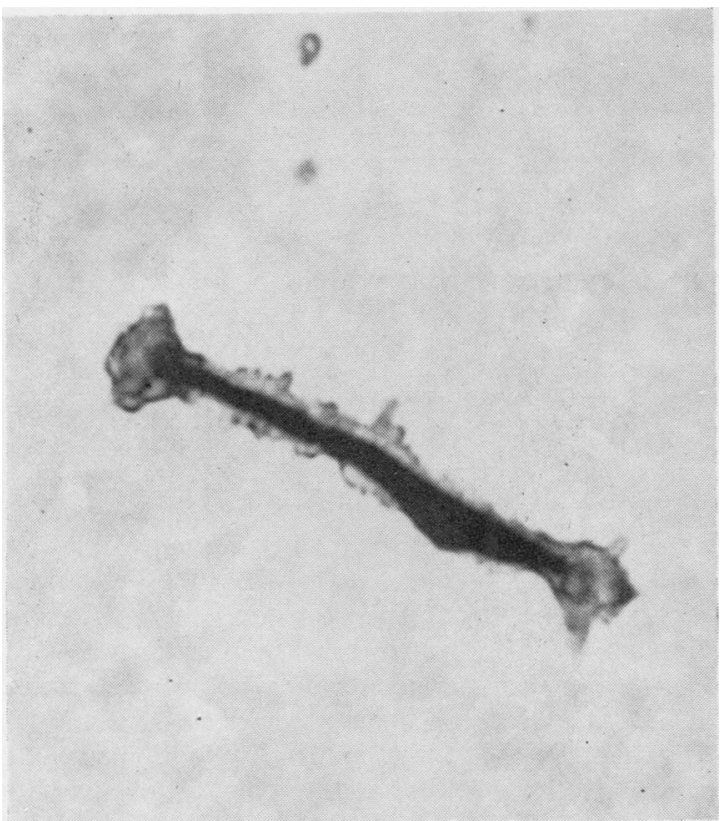

FIG. 2. Pseudo-asbestos body having black centre. Basal lung smear (unstained $\times 13,000$ ).

predominated with 82 cases in the fifth, sixth, and seventh decades.

ASBESTOS BODIES Asbestos bodies were found in 23 of the 100 cases $(23 \%)$. The bodies were all found in the 62 males $(37.0 \%)$, and none were found in the 38 females. Table I gives the age and sex distribution of the whole series and those cases showing asbestos bodies.

TABLE I

AGE AND SEX DISTRIBUTION OF 100 NECROPSY CASES AND THE 23 CASES SHOWING ASBESTOS BODIES

\begin{tabular}{|c|c|c|c|c|c|c|}
\hline \multirow{2}{*}{$\begin{array}{l}\text { Age } \\
\text { Groups } \\
\text { (yr.) }\end{array}$} & \multicolumn{3}{|c|}{ Number of Cases } & \multicolumn{3}{|c|}{ Asbestos Positive } \\
\hline & Male & Female & Total & Male & Female & Total \\
\hline $\begin{array}{l}21-30 \\
31-40 \\
41-50 \\
51-60 \\
61-70 \\
71-80 \\
81-90\end{array}$ & $\begin{array}{r}0 \\
0 \\
5 \\
12 \\
22 \\
19 \\
4\end{array}$ & $\begin{array}{r}2 \\
1 \\
3 \\
6 \\
12 \\
11 \\
3\end{array}$ & $\begin{array}{r}2 \\
1 \\
8 \\
18 \\
34 \\
30 \\
7\end{array}$ & $\begin{array}{r}0 \\
0 \\
1 \\
4 \\
11 \\
6 \\
1\end{array}$ & $\begin{array}{l}0 \\
0 \\
0 \\
0 \\
0 \\
0 \\
0\end{array}$ & $\begin{array}{r}0 \\
0 \\
1 \\
4 \\
1,1 \\
6 \\
1\end{array}$ \\
\hline Total & 62 & 38 & 100 & 23 & 0 & 23 \\
\hline
\end{tabular}

In 11 cases the asbestos bodies were found in the seventh decade, in which age group $50 \%$ of the male cases showed asbestos bodies. The youngest case in which asbestos bodies were found was a man of 46 years, described as a joiner in a shipyard; the oldest was an 84-year-old man said to be a 'retired engineer'.

NUMBER OF ASBESTOS BODIES IN SMEARS Although basal smears are believed to show the highest concentration of asbestos bodies, too much significance cannot be attached to the number of bodies seen in each case. The smears represent only a small random sample of the basal segments and give no indication as to the concentration of asbestos bodies in the whole lung. Table II gives the distribution of bodies found in the 23 positive cases.

\section{TABLE II}

NUMBER OF ASBESTOS BODIES FOUND IN 23 CASES

Number of Bodies Number of per 600 Low-power Cases Fields

$\begin{array}{rr}<5 & 11 \\ 5-10 & 2 \\ 11-20 & 4 \\ 21-30 & 0 \\ 31-40 & 0 \\ 41-50 & 1 \\ 51-60 & 1 \\ 61-70 & 0 \\ 71-80 & 1 \\ 81-90 & 0 \\ 91-100 & 0 \\ 101-110 & 0 \\ 111-120 & 1 \\ +350 & 1 \\ +400 & 1 \\ \text { Total } & 23\end{array}$

In 11 of the asbestos positive cases less than five asbestos bodies were seen in a total of 600 low-power fields. The maximum number of 430 bodies was counted in a man of 74 who died of a cerebral tumour and whose occupation was given as a riveter. Threehundred and fifty-seven bodies were seen in a 57year-old man, of unknown occupation, who died of a carcinoma of pancreas.

HYALINE Pleural PlaQues Hyaline or calcified parietal pleural plaques were looked for in 81 cases; they were present in $13(16.0 \%)$ and found only in males. In 11 of these cases $(85.4 \%)$ asbestos bodies were identified in the smears. In two cases, widespread bilateral calcified pleural plaques were found with no asbestos bodies in the smears; both these lungs were grossly oedematous and it may be that the concentration of the bodies depends to some extent on the degree of pulmonary congestion and oedema at the time of death. There were no cases of pleural or peritoneal mesotheliomata in the present series.

OCCUPATION The occupation was recorded in 18 
TABLE III

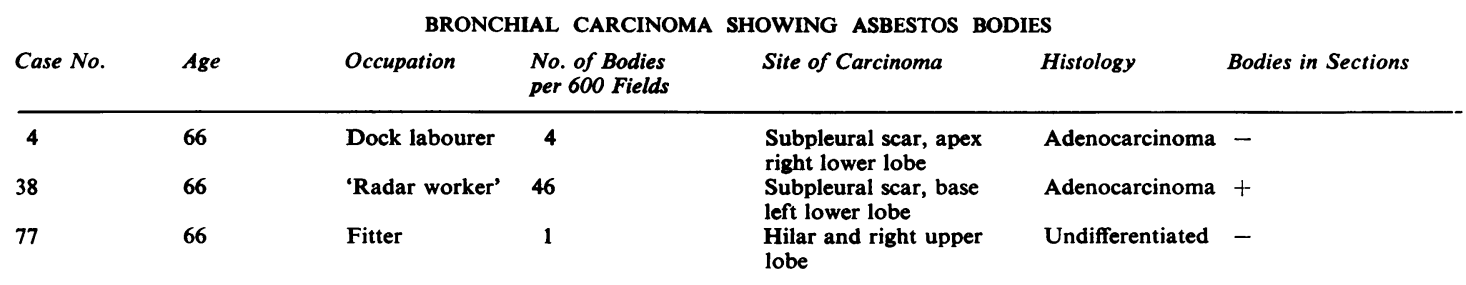

of the 23 positive cases, but further information as to the detailed nature of the work was not available. Among the occupations given were: dockworkers, fitters, joiners, turner, plater, coppersmith, bricklayer, labourer, railway porter, 'retired engineer', 'radar worker', youth trainer, and riveter.

In this short series there was no obvious correlation between occupation and the number of asbestos bodies found in the smears.

CAUSE OF DEATH In the 23 asbestos-body-positive cases, $12(52.1 \%)$ died of malignant disease. There were three cases of bronchial carcinoma as detailed in Table III.

Case 38 may be considered to be the only example of 'asbestosis' in this series. Although the right lower lobe scarring in case 4 is also possibly due to asbestosis no asbestos bodies were seen in the scar. There was also a history of widespread plumonary tuberculosis of the right lung some years before death which could explain the pulmonary scarring.

The remaining nine cases of malignant disease included stomach (three cases), kidney (two cases), pancreas (two cases), acute leukaemia (one case), and one case of a cerebral tumour.

\section{DISCUSSION}

The prevalence of asbestos bodies in lungs from routine hospital necropsies in difference parts of the world has recently been the subject of several reports (Table IV).

In addition, Hourihane and his colleagues state that in their material in London, asbestos bodies were found in $20-30 \%$ of necropsies (Hourihane, Lessof, and Richardson, 1966). These findings have led to the concept of urban contamination by asbestos. This is important when considering the relationship between long-term exposure to asbestos and subsequent development of pleural and peritoneal mesotheliomata, frequently without asbestosis.

In the present series, asbestos bodies were found in 23 of 100 consecutive adult necropsies $(23 \%)$. All were found in the 62 males $(37.0 \%)$. The results, while confirming the high incidence of asbestos bodies in hospital necropsies, differ from other reports in that no asbestos bodies were found in the 38 females. Although this series is small, it is comparable in size to the series reported by Cauna from Pittsburgh (Cauna, Totten, and Gross, 1965) in which asbestos bodies were found in $34 \%$ of 47 females. The findings in the present series suggest occupational exposure of the male, since if urban contamination were a factor it would be reasonable to assume that some asbestos bodies would have been found in females. It will be interesting to see whether these findings in females can be confirmed in larger series from other urban communities in Britain.

In this series, of the 23 cases showing asbestos bodies, 11 were in the seventh decade, in which age group $50 \%$ of the male cases showed asbestos bodies. Similarly Elmes and his colleagues (1965), 은 working in Belfast, found that $27 \%$ of males in the $\frac{7}{2}$ seventh decade showed asbestos bodies as compared to $14 \%$ in the sixth decade. The authors suggested $N$ that the difference in the two groups was related

TABLE IV

INCIDENCE OF ASBESTOS BODIES IN HOSPITAL NECROPSIES

\begin{tabular}{|c|c|c|c|c|c|c|c|}
\hline \multirow[t]{2}{*}{ Author } & \multirow[t]{2}{*}{ City } & \multicolumn{3}{|c|}{ Number of Cases } & \multicolumn{3}{|c|}{ Asbestos Bodies } \\
\hline & & Total & $\boldsymbol{M}$ & $\boldsymbol{F}$ & Total & $M$ & $F$ \\
\hline Thomson et al. (1963) & Cape Town & 500 & 306 & 194 & $\begin{array}{l}132 \\
(26.4 \%)\end{array}$ & $\begin{array}{l}93 \\
(30.4 \%)\end{array}$ & $\begin{array}{l}39 \\
(20.0 \%)\end{array}$ \\
\hline Cauna et al. (1965) & Pittsburgh & 100 & 53 & 47 & $\begin{array}{l}41 \%) \\
(41 \%)\end{array}$ & $\begin{array}{l}25 \\
(47 \%)\end{array}$ & $\begin{array}{l}16 \\
(34 \%)\end{array}$ \\
\hline Thomson et al. (1966) & Miami & 500 & 304 & 196 & $\begin{array}{l}136 \\
(27 \cdot 2 \%)\end{array}$ & $\begin{array}{l}96 \\
(31.6 \%)\end{array}$ & $\begin{array}{l}40 \\
(20.4 \%)\end{array}$ \\
\hline Present series & Glasgow & 100 & 62 & 38 & $\begin{array}{l}23 \\
(23 \%)\end{array}$ & $\begin{array}{l}23 \\
(37 \%)\end{array}$ & 0 \\
\hline
\end{tabular}


to the fact that the dangers of asbestos had been appreciated before the younger man started work. In Cape Town, there was a rise in the frequency of asbestos bodies in both sexes with age, to $30 \%$ in the over-65-years old (Thomson, Kaschula, and MacDonald, (1963). However, in Miami the highest incidence of asbestos bodies in males occurred in the 45-54-year age group (Thomson and Graves 1966); in Pittsburgh the highest relative incidence of positive cases was found between 25 and 34 years (Cauna et al., 1965). It appears that there are differences in the age and sex distribution of asbestos bodies from city to city. It may be that these differences are related to varying degrees of atmospheric contamination.

This series confirms the association between hyaline pleural plaques and the presence of asbestos bodies in the lungs (Hourihane et al., 1966). Parietal pleural plaques with or without calcification were found in 13 of 81 cases $(16.0 \%)$; in 11 of these $(85.4 \%)$ asbestos bodies were found in the basal smears. Hourihane and his colleagues stress the value of radiological surveys for calcified pleural plaques as an index to asbestos exposure. They can be equally valuable in necropsy studies as a pointer towards a closer examination of the lungs for scarring due to minimal asbestosis.

The present series is too small for any valid conclusions to be drawn as to the incidence of malignant disease in those showing asbestos bodies compared with those showing none.

Thanks are due to my colleagues Dr. A. Dick and Dr. Mary P. McEwan for collecting some of the smears; also to Mr. George Headden, F.I.M.L.T., for the photomicrographs.

\section{REFERENCES}

Cauna, D., Totten, R. S., and Gross, P. (1965). J. Amer. med. Ass., 192, 371.

Elmes, P. C., McCaughey, W. T. E., and Wade, O. L. (1965). Brit. med. J., 1,350 .

Hourihane, D. O'B., Lessof, L., and Richardson, P. C. (1966). Ibid., $1,1069$.

Thomson, J. G. (1965). Acad. N. Y. Acad Sci., 132, 196.

-, Kaschula, R. O. C., and MacDonald, R. R. (1963). S. Afr. med. J., 37, 77.

—_, and Graves, W. M., Jr., (1966). Arch. Path., 89, 458. 